\title{
FAKTOR-FAKTOR YANG BERHUBUNGAN DENGAN PERILAKU SEKSUAL PRANIKAH PADA SISWA SMA SAMARINDA
}

\author{
Sutrisno, Edi Purwanto, Rivan Firdaus \\ Jurusan Keperawatan, Poltekkes Kemenkes Kalimantan Timur, \\ Jl Wolter Monginsidi No.38 Samarinda \\ sutrisno@poltekkeskaltim.ac.id
}

\begin{abstract}
Premarital sexual behavior among adolescents is increasingly worrying and most of them are high school / vocational high school students. The aim of this study was to determine the factors associated with premarital sexual behavior in high school students in Samarinda City. Research outputs can be: Modules, International Journals, Seminars, Flip sheets and Leaflets on Premarital Sexual Behavior in Adolescents. The study used a cross sectional approach with a sample of 356 in 9 high schools and vocational schools in Samarinda, using the Slovin sample formula. There is a significant relationship between attitude, religiosity, and parenting factors with premarital sexual behavior among high school students in the city of Samarinda. There is no significant relationship between information source factors and premarital sexual behavior among high school students in Samarinda. It is very necessary to instill the values of good and positive attitudes for adolescents, especially in high school students as a reinforcement of premarital sexual understanding and its effects. There needs to be an increase in fostering the appreciation and practice of religious values in schools and the implementation of religious obligations while at both at school and at home. Open communication relations between parents and children are needed in order to implement good and democratic parenting.
\end{abstract}

Keywords: Teenagers, religiousity, Premarital Sexual Behavior

\begin{abstract}
Abstrak
Perilaku seksual pranikah pada remaja semakin mengkawatirkan dan sebagian besar adalah pelajar SMU/SMK. Penelitian ini bertujuan untuk mengetahui faktor-faktor yang berhubungan dengan perilaku seksual pranikah pada siswa SMA di Kota Samarinda. Penelitian menggunakan pendekatan cross sectional dengan jumlah sampel 356 pada 9 SMA dan SMK di kota Samarinda, menggunakan rumus sampel Slovin. Terdapat hubungan signifikan faktor sikap, religiusitas, dan pola asuh dengan perilaku seksual pranikah pada siswa SMA di kota Samarinda. Tidak terdapat hubungan signifikan faktor sumber informasi dengan perilaku seksual Pranikah pada siswa SMA di Kota Samarinda. Sangat dibutuhkan penanaman nilai-nilai sikap yang baik dan positif bagi para remaja khususnya pada siswa SMA sebagai penguatan terhadap pemahaman seksual pranikah beserta dampaknya. Perlu adanya peningkatan pembinaan penghayatan dan pengamalan nilainilai agama dalam sekolah serta pelaksanaan kewajiban agama saat berada dilingkungan sekolah maupun di rumah. Sangat dibutuhkan hubungan komunikasi terbuka antara orangtua dan anak dalam rangka melaksanakan pola asuh yang baik dan demokratis.
\end{abstract}

Kata Kunci : Remaja, Religius, Perilaku Seksual Pranikah 


\section{PENDAHULUAN}

Remaja adalah penduduk dalam rentang usia 10 hingga 19 tahun. Menurut Peraturan Menteri Kesehatan RI nomor 25 tahun 2014, remaja adalah penduduk dalam rentang usia 10-18 tahun. Sementara itu, menurut Badan Kependudukan dan Keluarga Berencana Nasional (BKKBN), rentang usia remaja adalah 10-24 tahun dan belum menikah (WHO, 2015). Jumlah penduduk Indonesia tahun 2016 yatu sebesar 258,7 juta jiwa dan meningkat pada 2017 yaitu 261,9 juta jiwa (BPS, 2018). Sedangkan jumlah penduduk Indonesia menurut kelompok umur dan jenis kelamin tahun 2017 usia 1014 tahun jenis kelamin laki-laki sebesar 11.639.907 dan perempuan 11.073.230, sedangkan usia 15-24 tahun laki-laki 11.365 .555 dan perempuan 10.847.326 (Dinas Kesehatan Provinsi Kalimantan, 2017).

Kota Samarinda pada tahun 2016 jumlah remaja laki-laki dan perempuan usia 10-14 tahun sebesar 969.164 jiwa yang menjadi populasi terbesar di samarinda setelah usia produktif, serta jumlah remaja laki-laki dan perempuan usia 15-18 tahun sebanyak 99.883 jiwa (Dinkes Kota Samarinda, 2017).

Menurut Survei Demografi dan Kesehatan Indonesia (SDKI, 2017), Kesehatan Reproduksi Remaja tahun 2017 persentase wanita dan pria belum kawin usia 15-24 tahun yang menyetujui hubungan seksual pranikah didapatkan hasil pada remaja pria yaitu $8 \%$ dan remaja wanita hanya $1 \%$. Saat remaja ditanya tentang pengalaman seksual pada remaja pria yaitu (8\%) dan remaja wanita (2\%).

Survey Perkumpulan Keluarga Berencana Indonesia (PKBI) Kalimantan Timur tentang perilaku remaja Samarinda tahun 2008 menyatakan, dari 300 remaja (usia 1320 tahun), 12\% mengaku sudah melakukan hubungan seks, 56\% diantaranya sudah melakukan hubungan layaknya suami istri pada usia antara 13-16 tahun. Survey dilakukan di kalangan remaja, dan sebagian besar adalah pelajar SMU/SMK.

Masa remaja merupakan masa transisi dari masa kanak-kanak ke masa dewasa yang ditandai dengan perubahan-perubahan fisik pubertas dan emosional yang kompleks, dramatis serta penyesuaian sosial yang penting untuk menjadi dewasa. Kondisi demikian membuat remaja belum memiliki kematangan mental, oleh karena masih mencari identitas atau jati dirinya sehingga sangat rentan terhadap berbagai pengaruh dalam lingkungan pergaulan termasuk dalam perilaku seksual (Sarwono, 2011). Adapun yang dimaksud perilaku seksual adalah segala tingkah laku yang didorong oleh hasrat seksual dengan lawan jenis maupun dengan sesama jenis. Perilaku seksual bisa bermacam-macam, mulai dari perasaan tertarik, sampai tingkah laku berkencan, bercumbu, dan bersenggama. Objek seksualnya bisa berupa orang lain, orang dalam 
khayalan atau diri sendiri (Sarwono, 2012).

Arus globalisasi yang begitu cepat berkembang membawa pengaruh komunikasi dan informasi yang begitu cepat dan tanpa hambatan sehingga dapat mempercepat adanya perubahan perilaku. Menurut penelitian yang dilakukan oleh Suryoputro, Ford and Shaluhiyah (2016) tentang faktorfaktor yang mempengaruhi perilaku seksual remaja di Jawa Tengah adalah, (1) faktor internal (pengetahuan, aspek-aspek kesehatan reproduksi, sikap terhadap layanan kesehatan seksual dan reproduksi, perilaku, kerentanan yang dirasakan terhadap resiko, kesehatan reproduksi, gaya hidup, pengendalian diri, aktifitas sosial, rasa percaya diri, usia, agama, dan status perkawinan), (2) faktor eksternal (kontak dengan sumber-sumber informasi, keluarga, sosial-budaya, nilai dan norma sebagai pendukung sosial untuk perilaku tertentu)

Ada beberapa faktor yang mempengaruhi perilaku seksual pada remaja salah satunya adalah hubungan keluarga dimana kurangnya dukungan keluarga seperti kurangnya perhatian orangtua terhadap anak, kurangnya kasih sayang orangtua, banyaknya konflik dalam keluarga dapat memicu munculnya perilaku seksual pranikah (Sarwono, 2012).

Perilaku seks bebas sangat besar dampaknya pada remaja sehingga pemerintah mengeluarkan PP Nomer 61 tahun 2014 tentang kesehatan reproduksi, (pasal 1); pelayanan kesehatan adalah suatu kegiatan dan serangkaian kegiatan pelayanan kesehatan bersifat promotif, preventif, kuratif dan rehabilitative (Kemenkes, 2014).

Banyaknya remaja yang memiliki perilaku seksual pra nikah khususnya di Samarinda yang sebagian besar adalah pelajar usia SMA, maka peneliti tertarik untuk mengetahui Faktor-faktor yang Berhubungan Dengan Perilaku Seksual Pra Nikah Pada Siswa SMA di Kota Samarinda.

\section{BAHAN DAN METODOLOGI PENELITIAN \\ Lokasi Penelitian}

Penelitian dilaksanakan pada bulan April-Agustus 2019 di Sekolah Menengah Atas yang berlokasi di Kota Samarinda Provinsi Kalimantan Timur baik Sekolah Negeri maupun Swasta.

\section{Rancangan Penelitian}

Peneliti menggunakan desain penelitian kuantitatif dengan rancangan analitik kuantitatif dengan pendekatan cross sectional

\section{Populasi dan Sampel}

Populasi dalam penelitian ini adalah seluruh siswa yang menempuh pendidikan pada di Sekolah Menengah Atas di Kota Samarinda dengan sampel sebanyak 356 siswa kelas XII di Kecamatan Samarinda Ulu.

\section{Metode Pengumpulan Data}

Metode sampling yang akan digunakan dalam penelitian ini adalah non probability sampling dengan metode consecutive sampling, yakni teknik pengambilan sampel yang 
dilakukan dengan cara memilih semua individu yang ditemui dan memenuhi kriteria inklusi, sampai jumlah sampel ynang diperlukan tercapai.

\section{Analisis Data}

Data yang telah dikumpulkan dianalisis secara univariat, bivariat dan multivariat menggunakan uji chi square untuk mengetahui faktor-faktor yang berhubungan dengan perilaku seksual pranikah pada siswa dan uji regresi logistik berganda untuk mengetahui faktor dominan yang berhubungan dengan perilaku seksual pranikah pada siswa.

\section{HASIL PENELITIAN}

Tabel 1 Karakteristik Responden berdasarkan Jenis Kelamin, Usia, Usia Pertama Kali Menstruasi dan Usia Pertama Kali Mimpi Basah.

\begin{tabular}{|c|c|c|}
\hline Variabel & $\mathbf{n}$ & $\%$ \\
\hline \multicolumn{3}{|l|}{ Jenis Kelamin } \\
\hline Laki-Laki & 86 & 44,3 \\
\hline Perempuan & 108 & 55,7 \\
\hline \multicolumn{3}{|l|}{ Usia } \\
\hline 15 & 15 & 7,7 \\
\hline 16 & 59 & 30,4 \\
\hline 17 & 104 & 53,6 \\
\hline 18 & 14 & 7,2 \\
\hline 19 & 2 & 1 \\
\hline \multicolumn{3}{|l|}{ Menarche } \\
\hline$\geq 14$ Tahun & 14 & 13,0 \\
\hline 13 Tahun & 28 & 26,0 \\
\hline 12 Tahun & 39 & 36,0 \\
\hline 11 Tahun & 22 & 20,4 \\
\hline$\leq 10$ Tahun & 6 & 5,6 \\
\hline \multicolumn{3}{|l|}{ Usia Pertama } \\
\hline \multicolumn{3}{|l|}{ Mimpi Basah } \\
\hline$\geq 15$ Tahun & 17 & 19,8 \\
\hline 14 Tahun & 25 & 29,1 \\
\hline 13 Tahun & 19 & 22,1 \\
\hline 12 Tahun & 20 & 23,1 \\
\hline$<11$ Tahun & 4 & 4,7 \\
\hline
\end{tabular}

kelamin perempuan $(55,7 \%)$ dan hampir setengahnya berjenis kelamin laki-laki (44,3\%). Sebagian besar responden berusia 17 tahun (53,6\%), hampir setengahnya berusia 16 tahun $(30,4 \%)$, sebagian kecil berusia 15 tahun $(7,7 \%), 18$ tahun $(7,2 \%)$ dan 19 tahun (1\%). Selanjutnya hampir sebagian siswi mengalami menstruasi pada usia 12 tahun $(36,0 \%), 13$ tahun $(26,0 \%)$ dan 11 tahun $(20,4 \%)$ dan sebagian kecil menstruasi diusia $\geq 14$ tahun $(13,0 \%)$ dan usia $\leq 10$ tahun $(5,6 \%)$. Selanjutnya, pada siswa putra hampir setengahnya responden mengalami mimpi basah pada usia $\geq 15$ Tahun $(19,8 \%) 14$ Tahun $(29,1 \%)$ 13 Tahun $(22,1 \%) 12$ Tahun $(23,1 \%)$ dan sebagian kecil pada usia $<11$ tahun $(4,7 \%)$.

Tabel 2 Determinan Perilaku Seksual Pranikah

\begin{tabular}{lcc}
\hline \multicolumn{1}{c}{ Variabel } & $\mathrm{n}$ & $\%$ \\
\hline Perilaku Seksual Pranikah & & \\
Risiko Ringan & 174 & 89,7 \\
Risiko Berat & 20 & 10,3 \\
Pola Asuh & & \\
Otoriter & 87 & 44,8 \\
Demokratis & 107 & 55,2 \\
Permisif & 0 & 0 \\
Penelataran & 0 & 0 \\
Sikap & & \\
Relatif Positif & 101 & 52,1 \\
Relatif Negatif & 93 & 47,9 \\
Religiusitas & & \\
Rajin & 150 & 77,3 \\
Tidak Rajin & 44 & 22,7 \\
Sumber Informasi & & \\
Terpapar & 185 & 95,4 \\
Tidak Terpapar & 9 & 4,6 \\
\hline
\end{tabular}

Tabel 2 menunjukkan bahwa sebagian kecil responden memiliki risiko berat melakukan seks pranikah 
(10,3\%), Responden mendapatkan pola asuh demokratis sebesar 55,2. Sikap positif ditunjukkan oleh $52,1 \%$ responden. Masih terdapat 22,7\% responden yang tidak rajin beribadah sesuai dengan agamanya. Hampir seluruh responden $(95,4 \%)$ telah mendapatkan informasi terkait perilaku seksual.

Tabel 3 Hubungan Variabel Independen dengan Variabel Dependen

\begin{tabular}{|c|c|c|c|c|c|c|c|c|}
\hline \multirow{3}{*}{ Determinan } & \multicolumn{4}{|c|}{ Perilaku Seksual } & \multicolumn{2}{|c|}{ Total } & \multirow{3}{*}{$\begin{array}{c}\mathbf{P} \\
\text { Value }\end{array}$} & \multirow{3}{*}{$\begin{array}{c}\text { OR } \\
(95 \% \mathrm{Cl})\end{array}$} \\
\hline & \multicolumn{2}{|c|}{ Risiko Ringan } & \multicolumn{2}{|c|}{ Risiko Berat } & \multirow{2}{*}{$\mathbf{n}$} & \multirow{2}{*}{$\%$} & & \\
\hline & $\mathbf{n}$ & $(\%)$ & $\mathbf{n}$ & (\%) & & & & \\
\hline \multicolumn{9}{|l|}{ Sikap } \\
\hline Relatif Positif & 95 & 94,1 & 6 & 0,1 & 101 & 100,0 & 0,037 & 2,806 \\
\hline Relatif Negatif & 79 & 84,9 & 14 & 15,1 & 93 & 100,0 & & $(1,030-7,641)$ \\
\hline \multicolumn{9}{|l|}{ Religiusitas } \\
\hline Rajin & 148 & 98,7 & 2 & 1,3 & 150 & 100,0 & 0,001 & 51,231 \\
\hline Tidak Rajin & 26 & 59,1 & 18 & 40,9 & 44 & 100,0 & & $\begin{array}{l}(11,214- \\
234,042)\end{array}$ \\
\hline \multicolumn{9}{|l|}{ Pola Asuh } \\
\hline Demokratis & 105 & 98,1 & 2 & 1,9 & 107 & 100,0 & 0,023 & 0,289 \\
\hline Otoriter & 69 & 79,3 & 18 & 20,7 & 87 & 100,0 & & $(0,97-0,861)$ \\
\hline \multicolumn{9}{|l|}{$\begin{array}{l}\text { Sumber } \\
\text { Informasi }\end{array}$} \\
\hline Terpapar & 9 & 100 & 0 & 0,0 & 4 & 100,0 & 0,298 & 1,121 \\
\hline Tidak Terpapar & 165 & 89,2 & 20 & 10,8 & 190 & 100,0 & & $(1,066-1,179)$ \\
\hline
\end{tabular}

Berdasarkan hasil uji chi-square pada tabel 3 menunjukkan bahwa faktor-faktor yang berhubungan dengan perilaku seksual pranikah antara lain sikap, religiusitas, dan pola asuh orang tua. Keterpaparan dengan sumber informasi tidak signifikan berhubungan dengan perilaku seksual pranikah.
Tabel 4 Hasil Uji Regresi Logistik Sederhana (Uji Kandidat)

\begin{tabular}{lcc}
\hline \multicolumn{1}{c}{ Variabel } & $\mathrm{P}$ & Keterangan \\
& Value & \\
\hline Pola Asuh & 0,001 & Kandidat \\
Sikap & 0,035 & Kandidat \\
Religiusitas & 0,001 & Kandidat \\
Sumber Informasi & 0,156 & Bukan Kandidat \\
\hline
\end{tabular}


Tabel 4 menunjukkan bahwa hasil uji regresi logistik terdapat 3 variabel memiliki nilai $p<0,25$ dan menjadi kandidat untuk dilakukan uji regresi logistik berganda yaitu pola asuh $(0,001)$, sikap $(0,035)$, sumber informasi $(0,156)$ dan religiusitas $(0,001)$.

Tabel 5 Hasil Uji Regresi Logistik Berganda

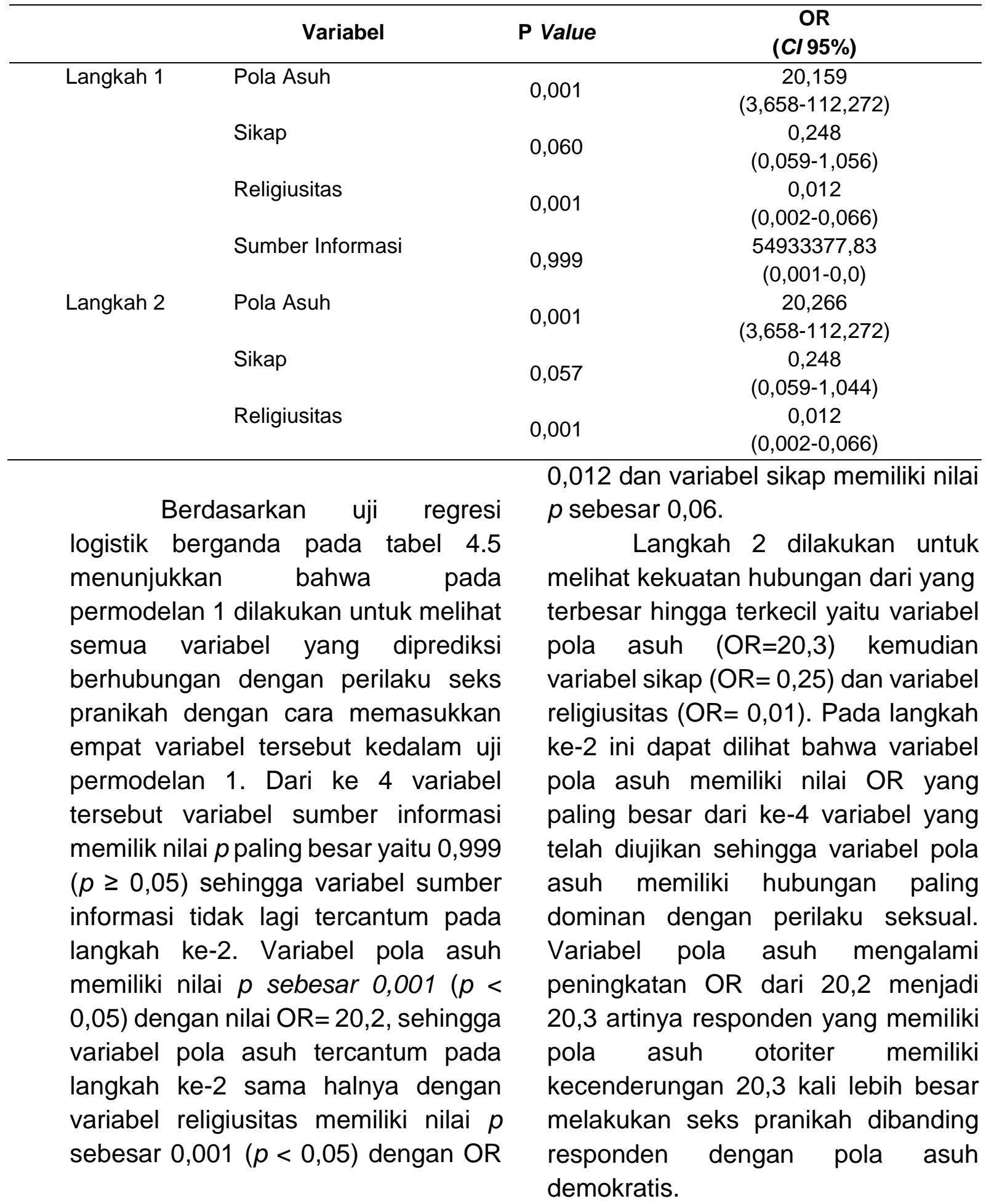


PEMBAHASAN

\section{Pola Asuh}

Hasil penelitian menunjukkan bahwa variabel pola asuh memiliki hubungan yang signifikan dan mengalami peningkatan OR dari 20,2 menjadi 20,3 artinya responden yang memiliki pola asuh otoriter memiliki kecenderungan 20,3 kali lebih besar melakukan seks pranikah dibanding responden dengan pola asuh demokratis.

Hasil penelitian tersebut didukung oleh penelitian Hargiyati, Hayati and Maidartati (2016), yang dilakukan pada anak remaja usia 1518 tahun di SMA X Kabupaten Bandung menggunakan analisi Chisquare dari Cramer's 0,001 atau $\mathrm{p}<$ 0,05 yang berarti pola asuh orang tua memiliki hubungan signifikan dengan perilaku seks pranikah remaja.

Menurut Kamus Besar Bahasa Indonesia (Depdiknas, 2008), pola asuh berasal dari dua kata yaitu pola dan asuh, pola yang berarti corak, model, sistem, cara kerja, bentuk (struktur) yang tetap. Sedangkan kata asuh dapat berarti menjaga (merawat dan mendidik) anak kecil, membimbing (membantu; melatih dan sebagainya), dan memimpin (mengepalai dan menyelenggarakan) satu badan atau lembaga. Menurut Chabib Thoha (dalam Al. Tridhonanto, 2014) mengemukakan bahwa pola asuh adalah salah satu cara terbaik yang dapat ditempuh orang tua dalam mendidik anak sebagai perwujudan dan rasa tanggung jawab kepada anak. Ahli lain, seperti Sam Vaknin (dalam (Al. Tridhonanto, 2014) mengutarakan bahwa pola asuh sebagai "parenting is interaction between parent's and children during their care". Suatu interaksi antara orang tua dan anak, dimana orang tua akan memberikan dorongan bagi anak dengan mengubah tingkah laku, pengetahuan, dan nilai-nilai yang dianggap paling tepat bagi orang tua agar anak bisa mandiri, tumbuh serta berkembang secara sehat dan optimal, memiliki rasa percaya diri, memiliki sifat rasa ingin tahu, bersahabat, dan berorietasi untuk sukses.

Pola asuh demokratis memberikan kesempatan untuk anak dalam pengambilan keputusan keluarga, berpendapat dan juga melakukan kontrol secara rasional, dengan cara yang mengakui dan menghormati perspektif anak-anak mereka. Orang tua yang responsif terhadap anak dapat dilihat dari sikapnya yang bersedia mendengar pertanyaan dari anak. Ketika anak gagal dalam memenuhi harapannya, orang tua memilih untuk memaafkan daripada menghukum anaknya.

Menurut Mussen (dalam Marcelina, 2013) ; faktor-faktor yang mempengaruhi pola asuh, yaitu: 1) Lingkungan tempat tinggal; keluarga yang tinggal dipedesaan dan dikota besar, berbeda gaya pengasuhannya. Keluarga yang tinggal di kota besar lebih memiliki kekhawatiran yang besar ketika anaknya keluar rumah daripada keluarga yang tinggal di desa. 2) Sub kultur budaya; dalam setiap pola asuh yang diterapkan berbeda-beda misalnya ketika disuatu 
budaya anak diperkenankan beragumen tentang aturan-aturan yang ditetapkan orang tua, tetapi hal tersebut tidak berlaku untuk semua budaya. 3) Status sosial ekonomi; keluarga yang memilii status sosial yang berbeda maka menerapkan pola asuh yang berbeda juga.

\section{Sikap}

Menurut Kitting et al., (2004), remaja lebih mudah dipengaruhi oleh perubahan lingkungan hidup, sosial dan budaya karena masa remaja adalah masa pencarian jati diri yang diterima oleh kelompoknya. Remaja mendapat banyak tekanan dari kelompoknya untuk diterima. Seringkali remaja tidak menyadari bahwa sikap berusaha diterima lingkungan bisa membuatnya terpapar pada perilaku berisiko.

Secord dan Backman dalam Azwar (2013) "Sikap adalah keteraturan tertentu dalam hal perasaan (afeksi), pemikiran (kognitif), dan predisposisi tindakan (konasi) seseorang terhadap suatu aspek dilingkungan sekitarnya". Sikap mungkin dihasilkan dari perilaku tetapi sikap tidak sama dengan perilaku.

Menurut (Azwar, 2013) struktur sikap dibedakan atas 3 komponen yang saling menunjang, yaitu komponen kognitif (kepercayaaan), afektif (emosional) dan konatif (kecenderungan untuk bertindak/bereaksi).

Hasil penelitian menunjukkan bahwa variabel sikap memiliki hubungan yang signifikan dan mengalami OR 4 artinya responden yang memiliki sikap yang relatif positif memiliki kecenderungan 4 kali lebih kecil melakukan seks pranikah dibanding responden dengan sikap yang relatif negatif. Hasil tersebut sejalan dengan penelitian yang dilakukan oleh Naja et al., (2017) dengan nilai $p=0,001 \quad(p<0,05)$ yang berarti ada hubungan signifikan antara sikap mengenai seksualitas dengan perilaku seks pranikah remaja SMA di kota Semarang.

Faktor-faktor

yang

mempengaruhi sikap menurut Azwar (2013), yaitu pengalaman pribadi, pengaruh orang lain, pengaruh kebudayaan, media massa, lembaga pendidikan dan lembaga agama serta faktor emosional.

Perubahan sikap menurut Kelman dalam Azwar (2013)ada tiga proses yang berperan dalam proses perubahan sikap yaitu :

1) Kesedihan. Terjadinya proses yang disebut kesedihan adalah ketika individu bersedia menerima pengaruh dari orang lain dan berharap untuk memperoleh reaksi positif, seperti pujian, dukungan, simpati, dan semacamnya sambil menghindari hal - hal yang dianggap negatif.

2) Identifikasi. Proses identifikasi terjadi apabila individu meniru perilaku tau sikap seseorang atau sikap sekelompok orang dikarenakan sikap tersebut sesuai dengan apa yang dianggapnya sebagai bentuk hubungan menyenangkan antara lain dengan pihak yang dimaksud

3) Internalisasi. Internalisasi terjadi apabila individu menerima 
pengaruh dan bersedia menuruti pengaruh itu dikarenakan sikap tersebut sesuai dengan apa yang ia percaya dan sesuai dengan system nilai yang dianutnya.

\section{Religiusitas}

Berdasarkan penelitian yang telah dilakukan didapatkan nilai $p=0,001$ yang berarti ada hubungan antara religiusitas dengan perilaku seks pranikah remaja. Remaja yang rajin beribadah memiliki kecenderungan 83,3 kali lebih kecil untuk melakukan seks pranikah dibanding dengan remaja yang tidak rajin beribadah. Hasil tersebut didukung oleh penelitian Luthfiah (2011)yang menyatakan bahwa ada hubungan antara religiusitas dengan perilaku seksual pranikah remaja.

Agama berperan besar dalam proses kehidupan manusia dan mampu menjadi terapi untuk mengatasi masalah patologi sosial. Sejak dulu kebebasan seksual dipandang sebagai masalah moral, dan dalam menanganinya, agama mengeluarkan seperangkat hukum legal yang melarang praktik asusila tersebut (Subayu, 2003). Melibatkan agama tidak berarti harus mengedepankan aspek yuridis, seperti menindak pelaku seksual dengan cara-cara yang tidak lagi manusiawi untuk ukuran masyarakat sekarang seperti hukuman rajam. Tetapi ada aspek lain yang bisa diangkat yakni pendidikan agama. Pendidikan agama harus mulai diangkat dan disosialisasikan kepada khalayak luas, khususnya remaja, baik dalam keluarga, sekolah, kampus, tempat ibadah maupun lingkungan kerja (Subayu, 2003). Seperti halnya saat ini, hampir semua sekolah mulai dari tingkat SD, SMP, SMA dan yg sederajat bahkan perguruan tinggi (PT) memiliki fasilitas ibadah, yaitu mesjid/mushola sebagai sarana pembinaan sekaligus pelaksanaan ibadah bagi murid-murid dilingkungan sekolah.

\section{Sumber Informasi}

Hasil penelitian menunjukkan nilai $p>0,05(p=0,99)$ berarti tidak ada hubungan antara sumber informasi dengan perilaku seks pranikah remaja. Hal tersebut tidak sejalan dengan penelitian yang dilakukan oleh Lestari et al., (2014)yang menyatakan bahwa ada hubungan antara sumber informasi dengan perilaku seks pranikah remaja menrutnya kemudahan akses pornografi melalui sumber informasi memberikan dampak negatif pada remaja dan memberikan informasi yang salah mengenai hubngan seksual antara pria dan wanita.

Remaja yang sedang dalam periode ingin tahu dan ingin mencoba, akan meniru apa yang dilihat atau didengar dari media massa, dan pada umumnya belum pernah mengetahui masalah seksual secara lengkap dari orang tua (Sarwono, 2012). Kecenderungan semakin meningkat oleh karena adanya penyebaran informasi dan rangsangan seksual melalui media massa yang dengan adanya teknologi canggih (video cassette, fotokopi, satelit, VCD, telepon genggan, internet dan lain- 
lain) menjadi tidak terbendung lagi dalam periode ingin tahu dan ingin mencoba tindakan perilaku seksual (Sarwono, 2012).

Informasi menurut Davis dalam Kadir (2003), adalah data yang telah diolah menjadi sebuah bentuk yang berarti bagi penerimanya dan bermanfaat bagi pengambilan keputusan saat ini atau saat mendatang. Informasi merupakan kumpulan data yang diolah menjadi bentuk yang lebih berguna dan lebih berarti bagi yang menerima.

Manfaat Informasi; informasi sangat beragam baik jenis, tingkatan maupun bentuknya. Jejaring sosial tersebut selain membawa manfaat positif juga membawa dampak negatif bagi remaja. Manfaat positifnya selain mempererat tali silaturahmi juga bisa mendapatkan informasi terbaru dari status orang lain sedangkan dampak negatifnya yaitu dapat mengganggu privasi, membuat ketagihan sehingga dapat mengganggu waktu untuk belajar dan dapat mempengaruhi para remaja untuk melakukan seks bebas (Wahyuningtias \& Wibisono, 2018).

Sumber informasi berperan penting bagi seseorang dalam menentukan sikap atau keputusan bertindak. Sumber informasi itu ada dimana-mana, di pasar-pasar, sekolah, rumah, lembaga-lembaga suatu organisasi komersial, bukubuku, majalah, surat kabar, perpustakaan dan tempat-tempat lainnya. Intinya dimana suatu benda atau peristiwa berada, disana bisa tercipta informasi yang kemudian direkam dan disimpan melalui media cetak ataupun media elektronik.

Menurut Yusup (2007) sumbersumber informasi dapat berupa buku, majalah, surat kabar, radio, tape recorder, CD-ROM, disket komputer, brosur, pamflet, dan media rekaman informasi lainnya merupakan tempat disimpannya informasi. Perpustakaan merupakan tempat yang menyediakan sumber-sumber informasi mulai dari informasi tercetak, seperti buku, majalah, novel, jurnal dan lain-lain sampai informasi yang berbentuk digital seperti internet. Internet memberikan kemudahan dalam mencari informasi karena memberikan fasilitas mesin pencari (search engine) dengan akses tanpa batas.

Banyak sekali informasi melalui media massa cetak, elektronik yang ditayangkan secara vulgar dan bersifat tidak mendidik, tetapi lebih cenderung mempengaruhi dan mendorong perilaku seksual yang tidak bertanggung jawab. Sehingga keterpaparan remaja terhadap pornografi semakin meningkat (Pinem, 2009). Konten pornografi bisa masuk dikarenakan banyak layanan jejaring sosial yang menyediakan kumpulan cara yang beragam bagi pengguna untuk dapat berinteraksi seperti chat, messaging, email, video, share file, blog, diskusi grup, dan lainlain. Media sosial paling sering digunakan di kalangan remaja antara lain: Facebook, Twitter, Path, Youtube, Instagram, Kaskus, Line, Whatsapp, Blackberry Messenger (Rahmawati \& Kusumawati, 2014). Situs pornografi yang dilihat membuat 
remaja ketagihan, selain itu tidak adanya kontrol dari keluarga dan minimnya pendidikan tentang reproduksi membuat kejadian seks bebas pada remaja semakin meningkat. Pornografi adalah gambar, sketsa, ilustrasi, foto, tulisan, suara, bunyi, gambar bergerak, animasi, kartun, percakapan, gerak tubuh, atau bentuk pesan lainnya melalui berbagai bentuk media komunikasi dan atau pertunjukan di muka umum, yang memuat kecabulan atau eksploitasi seksual yang melanggar norma kesusilaan dalam masyarakat.

\section{SIMPULAN DAN SARAN}

Kesimpulan dari penelitian ini adalah terdapat hubungan signifikan antara sikap, religiusitas, dan pola asuh dengan perilaku seksual pranikah pada siswa SMA dikota Samarinda. Untuk para guru sangat dibutuhkan penanaman nilai-nilai sikap yang baik dan positif bagi para remaja khususnya pada siswa SMA terhadap pemahaman seksual pranikah dan kesehatan reproduksi remaja melalui peningkatan pembinaan dan atau memasukakan pelajaran ke dalam kurikulum sekolah dan untuk para orang tua Sangat dibutuhkan hubungan komunikasi terbuka antara orangtua dan anak dalam rangka melaksanakan pola asuh yang baik dan demokratis.

\section{DAFTAR PUSTAKA}

Al. Tridhonanto, B. A. (2014). Mengembangkan Pola Asuh Demokratis. Elex Media Komputindo.
Azwar, S. (2013). Sikap Manusia: Teori dan Pengukurannya. Pustaka Belajar.

Depdiknas. (2008). Kamus Bahasa Indonesia. Pusat Bahasa Departemen Pendidikan Nasional.

https://bsd.pendidikan.id/data/um um/Kamus_Bahasa_Indonesia_2 008.pdf

Dinas Kesehatan Provinsi Kalimantan. (2017). Profil Kesehatan Kalimantan Timur Tahun 2017. In Dinkes Provinsi Kaltim. https://www.kemkes.go.id/resour ces/download/profil/PROFIL_KE S_PROVINSI_2017/23_Kaltim_2 017.pdf

Dinkes Kota Samarinda. (2017). Profil Kesehatan Kota Samarinda Tahun 2016. https://fdokumen.com/document/ profil-kesehatan-kota-samarindatahun-gambar-23-jumlahpenduduk-menurut-jenis.html

Hargiyati, I. A., Hayati, S., \& Maidartati. (2016). Perilaku Seks Pranikah Pada Remaja Usia (1518) Tahun Di SMA $X$ Kabupaten Bandung. Jurnal IImu Keperawatan, IV(2), 129-140. http://ejournal.bsi.ac.id/ejurnal/in dex.php/jk

Kadir, A. (2003). Pengenalan Sistem Informasi. Andi Offset Yogyakarta.

Kemenkes. (2014). Peraturan Pemerintah No. 61 Tahun 2014 tentang Kesehatan Reproduksi. In Kemenkes. Kemenkes RI. http://kesga.kemkes.go.id/image s/pedoman/PP No. 61 Th 2014 ttg 
Kesehatan Reproduksi.pdf

Kitting, A. ., Siregar, S. ., Kusumaryani, M. S. ., \& Hidayat, Z. (2004). Menyiapkan Generasi Muda yang Sehat \& Produktif: Kebutuhan akan Pelayanan dan Informasi Kesehatan Reproduksi. BKKBN bekerja sama dengan LD-FEUI \& Bank Dunia.

Lestari, I. A., Fibriana, A. I., \& Prameswari, G. N. (2014). FaktorFaktor Yang Berhubungan Dengan Perilaku Seks Pranikah Pada Mahasiswa Unnes. Unnes Journal of Public Health., 3(4), 27-38.

https://doi.org/10.15294/ujph.v3i4 .3903

Luthfiah, N. A. (2011). Hubungan Pemahaman Tingkat Agama (Religiusitas) dengan Perilaku Seks Bebas Pada Remaja di SMA N 1 Bangsal Mojokerto. Jurnal Keperawatan, 1.

Marcelina, W. D. (2013). Model Pola Asuh Orang Tua Yang Melakukan Perkawinan Usia Muda Terhadap Anak Dalam Keluarga (Di Desa Bermi, Kecamatan Krucil, Kabupaten Probolinggo) [UNIVERSITAS ISLAM NEGERI (UIN) MAULANA MALIK IBRAHIM MALANG].

http://etheses.uin-

malang.ac.id/1848/

Naja, Z. S., Agushybana, F., \& Mawarni, A. (2017). Hubungan Pengetahuan, Sikap Mengenai Seksualitas Dan Paparan Media Sosial Dengan Perilaku Seksual Pranikah Pada Remaja Di Beberapa SMA Kota Semarang
Triwulan II Tahun 2017. Jurnal Kesehatan Masyarakat, 5(4), 282-293.

https://ejournal3.undip.ac.id/inde x.php/jkm/article/view/18364

Pinem, S. (2009). Kesehatan Reproduksi dan Kontrasepsi. Trans Info Media.

Rahmawati, A., \& Kusumawati, E. (2014). Pengaruh Paparan Situs Jejaring Sosial Facebook Terhadap Sikap Seksual Remaja di Kota Semarang. Jurnal Kebidanan, 3(1), 49-57. https://jurnal.unimus.ac.id/index. php/jur_bid/article/view/1080

Sarwono, S. W. (2012). Psikologi Remaja. Raja Grafindo Persada.

SDKI. (2017). Survey Demografi dan Kesehatan Indonesia Tahun 2017. In Survei Demografi dan Kesehatan Indonesia. https://doi.org/0910383107 [pii] $\backslash r 10.1073 /$ pnas.0910383107 Subayu, R. (2003). Kembali Kepada Agama. Konferensi AIDS Internasional XV.

Suryoputro, A., Ford, N. J., \& Shaluhiyah, Z. (2006). FaktorFaktor Yang Mempengaruhi Perilaku Seksual Remaja Di Jawa Tengah: Implikasinya Terhadap Kebijakan dan Layanan Kesehatan Seksual dan Reproduksi. Makara Kesehatan, 10(1), 29-40. https://d1wqtxts1xzle7.cloudfront. net/36822618/a7362c598eb4125 460a36ee46447ac07ce7397c2.p df?1425285314=\&responsecontentdisposition=inline\%3B+filename 


\begin{abstract}
\%3DFAKTOR_FAKTOR_YANG_
MEMPENGARUHI_PERILAKU.p

df\&Expires $=1606671823 \&$ Signat

ure=Kt0UK63pQVekFmTySbGQ

EC4zI9
\end{abstract}

Wahyuningtias, H., \& Wibisono, W. (2018). Hubungan Penggunaan Sosial Media dan Pengetahuan Seks Bebas pada Siswa/Siswi Usia 17-18 Tahun. Jurnal Ners Dan Kebidanan, 5(2), 144-149. https://doi.org/10.26699/jnk.v5i2. art.p144-149

Yusup, P. M. (2007). Mengenal Dunia Perpustakaan dan Informasi. Bina Cipta. 